\title{
Torilin Inhibits Inflammation by Limiting TAK1-Mediated MAP Kinase and NF- $\kappa$ B Activation
}

\author{
Mehari Endale, ${ }^{1}$ Tae-Hwan Kim, ${ }^{2}$ Yi-Seong Kwak, ${ }^{3}$ Na-Mi Kim, ${ }^{3}$ Seung-Hyung Kim, ${ }^{4}$ \\ Jae Youl Cho, ${ }^{5}$ Bong-Sik Yun, ${ }^{6}$ and Man-Hee Rhee ${ }^{2}$ \\ ${ }^{1}$ Division of Neonatology and Pulmonary Biology, Cincinnati Children's Hospital Research Foundation, Cincinnati, OH, USA \\ ${ }^{2}$ College of Veterinary Medicine, Kyungpook National University, Daegu 702-701, Republic of Korea \\ ${ }^{3}$ Research and Development Headquarters, Korea Ginseng Corporation, Daejon 305-805, Republic of Korea \\ ${ }^{4}$ Institute of Traditional Medicine \& Bioscience, Daejeon University, Daejeon 300-716, Republic of Korea \\ ${ }^{5}$ Department of Genetic Engineering, Sungkyunkwan University, Suwon 440-746, Republic of Korea \\ ${ }^{6}$ College of Environmental \& Bioresource Sciences, Chonbuk National University, Iksan 570-752, Republic of Korea
}

Correspondence should be addressed to Bong-Sik Yun; bsyun@jbnu.ac.kr and Man-Hee Rhee; rheemh@knu.ac.kr

Received 9 October 2016; Accepted 27 December 2016; Published 20 February 2017

Academic Editor: Tânia Silvia Fröde

Copyright (C) 2017 Mehari Endale et al. This is an open access article distributed under the Creative Commons Attribution License, which permits unrestricted use, distribution, and reproduction in any medium, provided the original work is properly cited.

\begin{abstract}
Torilin, a sesquiterpene isolated from the fruits of Torilis japonica, has shown antimicrobial, anticancer, and anti-inflammatory properties. However, data on the mechanism of torilin action against inflammation is limited. This study aimed at determining the anti-inflammatory property of torilin in LPS-induced inflammation using in vitro model of inflammation. We examined torilin's effect on expression levels of inflammatory mediators and cytokines in LPS-stimulated RAW 264.7 macrophages. The involvement of NF-kB and AP-1, MAP kinases, and adaptor proteins were assessed. Torilin strongly inhibited LPS-induced NO release, iNOS, $\mathrm{PGE}_{2}, \mathrm{COX}-2, \mathrm{NF}-\alpha$, IL-1 $\beta$, IL-6, and GM-CSF gene and protein expressions. In addition, MAPKs were also suppressed by torilin pretreatment. Involvement of ERK1/2, P38 ${ }^{\mathrm{MAPK}}$, and JNK1/2 was further confirmed by PD98059, SB203580, and SP600125 mediated suppression of iNOS and COX-2 proteins. Furthermore, torilin attenuated NF-kB and AP-1 translocation, DNA binding, and reporter gene transcription. Interestingly, torilin inhibited TAK1 kinase activation with the subsequent suppression of MAPKmediated JNK, p38, ERK1/2, and AP-1 (ATF-2 and c-jun) activation and IKK-mediated I- $\kappa$ B $\alpha$ degradation, p65/p50 activation, and translocation. Together, the results revealed the suppression of NF- $\kappa \mathrm{B}$ and AP-1 regulated inflammatory mediator and cytokine expressions, suggesting the test compound's potential as a candidate anti-inflammatory agent.
\end{abstract}

\section{Introduction}

The study of such inflammatory responses including inflammatory mediators and cytokines activation is best characterized using suitable macrophage cell-lines including RAW 264.7 cells as models. In macrophages, LPS activates Tolllike receptor-4 (TLR4) and the activated receptor recruits the adaptor proteins (e.g., MyD88 or TRAM) and initiates MyD88 dependent or independent signaling pathways. MyD88 recruits and associates with two IL-1R-associated kinases (IRAK4 and IRAK1) leading to TNF receptor associated factor-6 (TRAF6) activation [1]. The activated TRAF6 is then ubiquitinated and recruited to the TGF $\beta$-activated kinase 1 (TAK1)-TGF $\beta$-activated kinase-1 binding protein
1 and $2(\mathrm{TAB} 1 / 2)$ complex via binding to TAB2 [2]. This promotes the activation of TAK1, which in turn activates the canonical NF- $\kappa \mathrm{B}[2]$ and the MAP kinases signaling pathways [3]. TAK1-TAB1/2 complex is thus a common route for the $\mathrm{I} \kappa \mathrm{B}$ kinase (IKK) and for MAPKs pathways (ERK1/2, JNK, and p38) [4]. These signaling pathways in turn activate a variety of transcription factors including NF-kB (p50/p65) and AP1 (c-Fos/c-Jun) that coordinate the induction of many genes encoding inflammatory mediators [5]. These mediators such as iNOS, COX-2, and cytokines (TNF- $\alpha$, IL-1 $\beta$, IL-6, and GM-CSF) are the common inflammatory mediators transcriptionally regulated by the above indicated transcription factors [6]. Therefore, targeting these transcription factors, adaptor proteins, protein kinases, inflammation mediators, or 
cytokines themselves by natural products or their derivatives can be an effective strategy for immunosuppression [7].

Natural products are reported to be better candidates of therapeutics due to their chemical diversity, structural complexity, affordability, lack of substantial toxicity, and inherent biologic activities [8]. Salminen et al. further indicated that a number of natural products have demonstrated NF- $\kappa \mathrm{B}$-inhibitory activities such as attenuation of IKK activation, $\mathrm{I} \kappa \mathrm{B}$ degradation, $\mathrm{NF}-\kappa \mathrm{B}$ nuclear translocation, and DNA binding [9]. A large body of evidences also indicated anti-inflammatory effects of natural products against MAP kinases. Modulation of NF- $\kappa \mathrm{B}$ and MAP kinases signaling pathways is therefore a principal target to alleviate inflammatory diseases including arthritis [10]. Recently, however, the demand for anti-inflammatory agents that can treat inflammation and arthritis but remain relatively free of side effects in long term treatment increases.

A large number of plant-derived compounds including natural terpenoids as powerful inhibitors of NF-kB and MAP kinases are reported to be suppressive agents of inflammation and cancer $[9,11]$. Evidently, a number of terpenoids are reported to affect some upstream targets as they inhibit the NF-kB and MAPK pathways simultaneously and further potentiate the suppression of inflammatory responses $[9,12]$. Sesquiterpenes are most widely published class of natural products cited as inhibitors of NF- $\kappa$ B. For instance, parthenolide, a sesquiterpenes, is reported to inhibit NF$\kappa \mathrm{B}$ via inhibition of $\mathrm{I} \kappa \mathrm{B} \alpha / \mathrm{I} \kappa \mathrm{B} \beta$ degradation [13] and $\mathrm{IKK} \beta$ activation [14] and modification of $\mathrm{NF}-\kappa \mathrm{B}$ via alkylation [15-17]. However, information on the mechanism of antiinflammatory property of torilin, another sesquiterpene, is limited.

Torilin (11-acetoxy-8-angeloyl-4-guaien-3-one), a guaiane-type sesquiterpene angelate, is isolated from the fruits of the plant Torilis japonica [18]. Previous studies on torilin indicated that the compound exhibits antiprotozoal [19] and antimicrobial [20] effects. Besides, it is reported to reverse multidrug-resistance [21] and show antiangiogenic as well as anti-invasive properties [22, 23].

Although few reports have been documented on the antiinflammatory potential of torilin [24, 25], studies detailing the mechanism of action behind its anti-inflammatory effect using macrophage cells line (suitable models for studying inflammatory responses) are limited. Since torilin has been shown to possess anti-inflammatory activities in vitro and in vivo $[24,25]$, we previously have reported that torilin modifies inflammatory cell and cytokine imbalances with the attenuation of the severity of arthritis in mouse model of rheumatoid arthritis [26]. However, its molecular mechanism of action against inflammatory responses has not been reported yet. The aim of this study was therefore to examine the upstream events in the anti-inflammatory property of torilin and to elucidate its underlying mechanisms of action. Here, we report that torilin markedly inhibited inflammatory mediators and cytokines via inhibition of TAK1-mediated MAPK, AP-1, and NF-kB activation.

\section{Materials and Methods}

Primary antibodies for iNOS, COX-2, $\beta$-actin, PARP, phospho-PI3K p85, PI3K, Akt, phospho-Akt, NF- $\kappa$ B, phosphoNF- $\kappa \mathrm{B}, \mathrm{I} \kappa \mathrm{B}-\alpha$, phospho-I $\kappa \mathrm{B}-\alpha$, IKK $\beta$, phospho-IKK $\alpha / \beta$, phospho-p38, p38 ${ }^{\mathrm{MAPK}}$, phospho-JNK, JNK, phosphoERK1/2, ERK1/2, MKK4, MKK6, MyD88, IRAK1, TRAF6, phosphor-TAK1, TAK1, phospho-c-fos, phosphor-c-jun, phosphor-ATF2, IL-1 $\beta, \mathrm{TNF} \alpha$, and horseradish peroxidaseconjugated secondary antibody were from Cell Signaling Technology (Danvers, MA, USA). SB203580, SP600125, and PD98059 were from Sigma-Aldrich (St. Louis, MO). Consensus oligonucleotides for NF- $\kappa$ B and AP-1 were obtained from Santa Cruz Biotechnology (Santa Cruz, CA). $\gamma^{-32}$ P-Labeled ATP was purchased from ICN (Costa Mesa, CA). A prostaglandin $\mathrm{E}_{2}$ EIA kit was from Enzo life Sciences (Ann Arbor, MI, USA). Easy Blue ${ }^{\mathrm{TM}}$ RNA extraction kit was from iNtRON, Korea. Millipore MILLIPLEX ${ }^{\mathrm{TM}}$ Mouse Cytokine/Chemokine enzyme-linked immunosorbent assay kit was from Millipore Corp. (St. Charles, MO). All materials, equipment, and biotinylated marker proteins for gel electrophoresis were from Bio-Rad. All other chemicals were purchased from Sigma-Aldrich (St. Louis, MO) unless otherwise stated. Torilin (98\%) was prepared as previously indicated in [26] and dissolved in dimethyl sulfoxide and freshly diluted in culture media for all experiments.

2.1. Cell Culture. RAW 264.7 murine macrophages, obtained from the American cell collection (ATCC TIB71), were grown in Dulbecco's modified Eagle's medium (DMEM) (Invitrogen, Carlsbad, CA), supplemented with $10 \%$ fetal bovine serum, $2 \mathrm{mM}$ L-glutamine, $100 \mathrm{UmL}^{-1}$ penicillin, and $100 \mu \mathrm{gmL}^{-1}$ streptomycin. They were incubated under endotoxin-free conditions at $37^{\circ} \mathrm{C}$ in a $5 \% \mathrm{CO}_{2}$ humidified air incubator.

2.2. Cell Viability. The RAW 264.7 cells were plated at a density of $5 \times 10^{4}$ cells/well in a 96 -well plate for $24 \mathrm{~h}$. To determine any potential cytotoxic effect of the test compound, cells were treated with torilin or vehicle before incubation for $48 \mathrm{~h}$. The 3-(4,5-dimethylthiazol-2-yl)-2,5-diphenyltetrazolium bromide (MTT, $0.5 \mathrm{mgmL}^{-1}$ ) was added and cells were incubated for $4 \mathrm{~h}$. The media were then removed, and produced formazan crystals in the wells were dissolved by addition of $200 \mathrm{~mL}$ dimethyl sulfoxide (DMSO). Absorbance was measured at $540 \mathrm{~nm}$ using Synergy HT Multi-Model Microplate Reader (BioTek Instrument, Winooski, USA). Cell viability (\% control) was defined relative to untreated control cells.

2.3. Nitrite (NO) Production. RAW 264.7 macrophages were plated in 96 -well plates $\left(2 \times 10^{5}\right.$ cells/well $)$ and incubated overnight. The cells were treated with torilin or vehicle $30 \mathrm{~min}$ before LPS stimulation for $24 \mathrm{~h}$. NO production was determined via quantitation of nitrite levels in cell culture supernatants according to the Griess reaction with the absorbance measured at $540 \mathrm{~nm}$.

2.4. Enzyme-Linked Immunosorbent Assay. RAW 264.7 cells were preincubated with torilin for $30 \mathrm{~min}$ before LPS stimulation for $24 \mathrm{~h}$, and cytokine contents in the culture medium were measured by ELISA using anti-mouse TNF- $\alpha$, IL- $1 \beta$, IL6 , and GM-CSF antibodies and biotinylated secondary antibodies following the manufacturer's instruction (Millipore MILLIPLEX $^{\text {тм }}$ Mouse Cytokine/Chemokine kit (Millipore 
Corp., St. Charles, $\mathrm{MO}, \mathrm{USA})$ ). In addition, $\mathrm{PGE}_{2}$ contents in the culture medium were measured using prostaglandin $\mathrm{E}_{2}$ kit according to the manufacturer's instruction (Enzo life Sciences, Ann Arbor, MI, USA).

2.5. RNA Isolation and Reverse Transcription PCR. Total cellular RNA from $3 \times 10^{6}$ RAW 264.7 macrophages treated with torilin or vehicle was extracted as described previously [27] using Easy Blue kits (iNtRON Biotechnology, Korea) according to the manufacturer's instructions and stored at $-70^{\circ} \mathrm{C}$ until use. Briefly, $1 \mu \mathrm{g}$ RNA was annealed with poly $(\mathrm{dT})_{18}$ for $10 \mathrm{~min}$ at $70^{\circ} \mathrm{C}$ and cooled for $5 \mathrm{~min}$ on ice, reverse transcribed using reverse transcription (RT) premix (Bioneer) in $20 \mu \mathrm{l}$ of reaction mixture containing $5 \mathrm{x}$ buffer (10 mM dNTP, $0.1 \mathrm{mM}$ dithiothreitol, and $2 \mathrm{U}$ of murine leukemia virus reverse transcriptase), and run for $90 \mathrm{~min}$ at $42.5^{\circ} \mathrm{C}$ using a thermal cycler. The reactions were terminated at $95^{\circ} \mathrm{C}$ for $5 \mathrm{~min}$ to inactivate the reverse transcriptase. The reverse transcription polymerase chain reaction (RT-PCR) was performed using aliquots of cDNA obtained from RT reaction in a PCR premix (Bioneer) containing a 10x buffer [10 mM Tris $\cdot \mathrm{HCl}(\mathrm{pH} 8.3), 50 \mathrm{mM} \mathrm{KCl}, 0.1 \%$ Triton X-100, $0.25 \mathrm{mM}$ dNTP, $25 \mathrm{mM} \mathrm{MgCl}_{2}$, and $1 \mathrm{U}$ of Taq polymerase]. Amplification conditions were $5 \mathrm{~min}$ before denaturation at $95^{\circ} \mathrm{C}$ followed by $30-35$ cycles consisting of denaturation at $95^{\circ} \mathrm{C}$, annealing at $55-60^{\circ} \mathrm{C}$, and elongation at $72^{\circ} \mathrm{C}$ for 45 second each with final extension for $10 \mathrm{~min}$ at $72^{\circ} \mathrm{C}$. The PCR products were electrophoresed in $1.3 \%$ agarose gel stained with ethidium bromide and visualized using Eagle Eyes image analysis software (Stratagene, La Jolla, CA). The intensity of band densities for iNOS, COX-2, TNF- $\alpha$, IL-1 $\beta$, IL-6, and GM-CSF mRNA expression levels were normalized for the corresponding GAPDH and ratios were compared. The sequence of oligonucleotides used was as follows: iNOS: (forward-5'-GTG CTG CCT CTG GTC TTG CAA GC-3', reverse- ${ }^{\prime}$-AGG GGC AGG CTG GGA ATT CG-3 ${ }^{\prime}$ ); COX-2: (forward- $5^{\prime}$-TCT CAG CAC CCA CCC GCT CA- $3^{\prime}$, reverse$5^{\prime}$-TCT CAG CAC CCA CCC GCT CA-3'); IL-1 $\beta$ : (forward$5^{\prime}$-TGC TTC CAA ACC TTT GAC CTG GGC- $3^{\prime}$, reverse$5^{\prime}$-CAG GGT GGG TGT GCC GTC TTT C- $3^{\prime}$ ); TNF- $\alpha$ : (forward-5' -CCT GTA GCC CAC GTC GTA GC-3', reverse$5^{\prime}$-TTG ACC TCA GCG CTG AGT TG-3'); IL-6: (forward$5^{\prime}$-GCT GGA GTC ACA GAA GGA GTG GC- $3^{\prime}$, reverse$5^{\prime}$-GGC ATA ACG CAC TAG GTT TGC CG-3'); GM-CSF: (forward-5'-ACT CTG CTC ACG AAG GAA CTC AGC$3^{\prime}$, reverse- $5^{\prime}$-CAC AGC TCG GAA GAG CAT CGC A-3'); GAPDH: (forward-5' -CAC TCA CGG CAA ATT CAA CGG C- $3^{\prime}$, reverse- $5^{\prime}$-CCT TGG CAG CAC CAG TGG ATG CAG G-3 ${ }^{\prime}$.

2.6. Immunoblotting. RAW 264.7 macrophages were washed with PBS and lysed in standard lysis buffer $[20 \mathrm{mM}$ Tris- $\mathrm{HCl}$ (pH 7.5), $1 \%$ Triton X-100, $137 \mathrm{mM} \mathrm{NaCl}, 10 \%$ glycerol, $2 \mathrm{mM}$ EDTA, $1 \mathrm{mM}$ sodium orthovanadate, $25 \mathrm{mM} \beta$-glycerophosphate, $2 \mathrm{mM}$ sodium pyrophosphate, $1 \mathrm{mM}$ phenylmethylsulfonyl fluoride and $1 \mathrm{mgmL}^{-1}$ leupeptin, $2 \mathrm{mgmL}^{-1}$ aprotinin, and $1 \mathrm{mgmL}^{-1}$ pepstatin $\left.\mathrm{A}\right]$. Lysates were centrifuged at $10,000 \times \mathrm{g}$ for $10 \mathrm{~min}$ and supernatant was stored at $-70^{\circ} \mathrm{C}$ until use. Protein was then measured using
Bicinchoninic Acid (BCA, Pierce, USA) protein assay kit with bovine serum albumin used as a standard. Equal amounts of protein $(30-40 \mu \mathrm{g} / \mathrm{lane})$ were loaded with sample buffer $(250 \mathrm{mM}$ Tris-HCl, pH 6.8, 0.5 M DTT, 10\% SDS, $50 \%$ glycerol, $5 \% \beta$-mercaptoethanol, and $0.5 \%$ bromophenol blue) and electrophoresed on 8-12\% SDS-polyacrylamide gel under standard conditions and electroblotted to polyvinylidene difluoride membranes (PVDF) (Millipore Co., MA, USA) in $20 \%$ methanol transfer buffer. The membranes were washed three times with Tris-buffered saline containing $0.01 \%$ Tween-20 (TBS-T) and blocked with 5\% nonfat milk, washed, and incubated with primary antibodies diluted $(1: 1000)$ overnight at $4^{\circ} \mathrm{C}$. The membranes were then incubated with secondary antibodies conjugated with horseradish peroxidase for $1 \mathrm{~h}$ at room temperature. Scanning densitometry of the immunoblots was performed with an Image Scan and Analysis System (Alpha-Innotech, San Leandro, CA, USA). The area of each lane was integrated using the software Alpha Ease version 5.5 (Alpha-Innotech) followed by background subtraction.

2.7. Immunoprecipitation and In Vitro TAK1 Kinase Assays. Cell lysates containing equal amounts of protein $(500 \mu \mathrm{g})$ from RAW $264.7\left(10^{7}\right.$ cells $\left./ \mathrm{ml}\right)$ treated with torilin or vehicle $30 \mathrm{~min}$ before LPS stimulation for $15 \mathrm{~min}$ were precleared with $10 \mu \mathrm{L}$ protein A-coupled Sepharose magnetic beads (10\% $\mathrm{v} / \mathrm{v}$; ELPIS Biotech, Korea) for $1 \mathrm{~h}$ at $4^{\circ} \mathrm{C}$. Precleared samples were incubated with $3 \mu \mathrm{L}$ anti-TAK1 antibody overnight at $4^{\circ} \mathrm{C}$. Immune complexes were mixed with $10 \mu \mathrm{L}$ protein Acoupled Sepharose magnetic beads (10\% v/v) and incubated for $4 \mathrm{~h}$ at $4^{\circ} \mathrm{C}$. The immune-precipitates were then washed 5 times with immunoprecipitation (IP) buffer $(20 \mathrm{mM}$ Tris$\mathrm{HCl}$, pH 7.4; 2 mM EDTA, 2 mM EGTA, 50 mM $\beta$-glycerophosphate, $5 \mathrm{mM} \mathrm{NaF}, 1 \mathrm{mM}$ sodium orthovanadate, $1 \%$ Triton X-100, $10 \%$ glycerol, $10 \mu \mathrm{g} / \mathrm{ml}$ aprotinin, $10 \mu \mathrm{g} / \mathrm{ml}$ pepstatin, $1 \mathrm{mM}$ PMSF, $1 \mathrm{mM}$ benzimide, and $2 \mathrm{mM}$ hydrogen peroxide). After washing, the beads were boiled in Laemmli sample buffer ( $2 \%$ sodium dodecyl sulfate [SDS], $1 \% \beta$ mercaptoethanol, $0.008 \%$ bromophenol blue, $80 \mathrm{mM}$ Tris $\mathrm{pH}$ 6.8 , and $1 \mathrm{mM}$ EDTA) and the proteins were resolved by SDS-PAGE and transferred to PVDF membranes, blocked, and probed with anti-p-TAK1, TAK1, p-IKK $\alpha / \beta$, IKK, pMKK4, MKK4, anti-TLR4, and $\beta$-actin antibodies. Then, immunoblots were visualized as indicated above.

For evaluating TAK1 kinase activities following immunoprecipitation, the beads were washed in IP buffer and then in kinase reaction buffer $[100 \mathrm{mM}$ Tris- $\mathrm{HCl}, \mathrm{pH} 7.2 ; 125 \mathrm{mM} \mathrm{Mg}$ $\left(\mathrm{C}_{2} \mathrm{H}_{3} \mathrm{O}_{2}\right)_{2} ; 25 \mathrm{mM} \mathrm{MnCl} 2 ; 2 \mathrm{mM}$ EGTA; $0.25 \mathrm{mM}$ sodium orthovanadate; and $2 \mathrm{mM} \mathrm{DTT}$ ] and then resuspended in kinase buffer containing $1 \mu \mathrm{m}$ ATP and $12.5 \mu \mathrm{Ci}$ of $\gamma^{-32}$. After $5 \mathrm{~min}$ of incubation at $30^{\circ} \mathrm{C}$, the reaction was terminated by lysis buffer.

2.8. Preparation of Nuclear Extracts. Prior to nuclear extraction, cells $\left(5 \times 10^{6} /\right.$ well $)$ were washed twice with ice-cold PBS centrifuged and the pellet was suspended by adding $400 \mu$ l of buffer A [10 mM HEPES (pH 7.9), $10 \mathrm{mM} \mathrm{KCl,} 2 \mathrm{mM}$ $\mathrm{MgCl}_{2}, 0.1 \mathrm{mM}$ EDTA, $1 \mathrm{mM}$ dithiothreitol and $0.5 \mathrm{mM}$ 
phenylmethylsulfonyl fluoride (PMSF), $2 \mu \mathrm{gmL}^{-1}$ of leupeptin, aprotinin, and pepstatin]. After centrifugation at $10,000 \times \mathrm{g}$ for $5 \mathrm{~min}$, pellet was resuspended with buffer $\mathrm{A}$ and 5\% Nonidet-P40 and centrifuged at $13,000 \times \mathrm{g}$ for $2 \mathrm{~min}$ and the supernatant was used as cytosolic extract. The pellets containing crude nuclei were resuspended in $400 \mu \mathrm{l}$ buffer A centrifuged at $10,000 \times \mathrm{g}$ for $5 \mathrm{~min}$ twice. The pellets were again resuspended with buffer B containing $10 \mathrm{mM}$ HEPES [(pH 7.9), $300 \mathrm{mM} \mathrm{NaCl}, 0.1 \mathrm{mM}$ EDTA, $1 \mathrm{mM}$ DTT and $1 \mathrm{mM}$ PMSF, $5 \mu \mathrm{gmL}^{-1}$ leupeptin, aprotinin, and pepstatin each and 10\% glycerol] and incubated with rocking for $20 \mathrm{~min}$ on ice. The samples were centrifuged at $15,800 \times \mathrm{g}$ for $10 \mathrm{~min}$ to obtain the supernatant containing nuclear extracts. Protein concentration of the supernatant was determined.

2.9. Electrophoretic Mobility Shift Assay. RAW 264.7 macrophages $\left(3 \times 10^{6}\right.$ cells $)$ were treated with torilin or vehicle and stimulated with LPS for $45 \mathrm{~min}$, washed, scraped into $0.5 \mathrm{ml}$ cold PBS, and pelleted by centrifugation. Cytosolic and nuclear protein fractions were extracted using active motif nuclear extraction kit (Carlsbad, CA, USA). Binding reactions were performed at $37^{\circ} \mathrm{C}$ for $15 \mathrm{~min}$ in $20 \mu \mathrm{l}$ of reaction buffer containing $[10 \mathrm{mM}$ Tris- $\mathrm{HCl}, \mathrm{pH} 7.5,50 \mathrm{mM}$ $\mathrm{NaCl}, 1 \mathrm{mM}$ EDTA, $10 \%$ glycerol, $1 \mu \mathrm{g}$ poly(dI-dC), $1 \mathrm{mM}$ dithiothreitol, and 30,000 cpm ${ }^{32}$ P-labeled oligonucleotide probes] for NF- $\kappa \mathrm{B}$ and AP-1. DNA-protein complexes were separated from unbound DNA probe on native $6 \%$ polyacrylamide gels at $75 \mathrm{~V}$ in $0.5 \mathrm{x}$ TBE buffer and then transferred to nylon membrane.

2.10. Transient Transfection Luciferase Assay. Transient transfections of RAW 264.7 cells with MyD88, NF- $\kappa$ B, and AP1 promoter firefly luciferase construct were performed in triplicate in 24-well plates using Lipofectamine ${ }^{\mathrm{TM}} 2000$ (Invitrogen, CA, USA). The reporter activity was measured using a luciferase assay system according to the manufacturer's instructions. Briefly, $6 \mathrm{hr}$ after treatment, cells were washed twice with ice-cold PBS (pH 7.4) and lysed by adding $200 \mu \mathrm{l}$ of $1 \mathrm{x}$ reporter lysis buffer (Promega). After centrifugation at $12,000 \times \mathrm{g}$ for $10 \mathrm{~min}$ at $4^{\circ} \mathrm{C}$, the supernatant was analyzed for luciferase activity and normalized to $\beta$-galactosidase activity.

2.11. Statistical Analysis. Data were analyzed by one-way analysis of variance with Dunnett's post hoc test. Experiments represent at least 4 independent replications in triplicate. Values are means \pm SE and treatment groups were compared by $t$-test. $P<0.05$ was considered statistically significant.

\section{Result}

3.1. Torilin Inhibits LPS-Induced Inflammatory Mediator and Cytokine Expressions. Because torilin has been described as sesquiterpene with anti-inflammatory activity in BV2 cells [25], we examined the anti-inflammatory mechanisms of the compound using a suitable macrophage RAW 264.7 cell-line model. Toxicity screening showed that torilin did not exhibit cytotoxicity in RAW 264.7 (Supplementary Figure 1 in Supplementary Material available online at https://doi.org/10.1155/2017/7250968). Torilin pretreatment dose-dependently inhibited NO generation and iNOS protein and gene expressions (Figures 1(a), 1(c), and 1(d)), respectively. In addition, prostaglandin (PG)E2 and COX-2 protein and mRNA expressions were markedly suppressed by torilin (Figures 1(b), 1(e), and 1(f)). Torilin further arrested LPSinduced proinflammatory cytokines including TNF- $\alpha$, IL- $1 \beta$, IL-6, and GM-CSF protein secretion (Figures 2(a)-2(d)) and protein and mRNA expressions (Supplementary Figure 2AF), respectively. These data suggested that torilin may elicit its overall anti-inflammatory effects at the level and/or upstream of inflammatory gene transcriptions.

3.2. Effect of Torilin on LPS-Induced MAP Kinases and PI3kAkt Activation. We examined the possible involvement of MAPK and PI3K/Akt signaling pathways in torilin mediated inhibition of inflammatory mediators. As shown in Figures 3(a) and 3(b), torilin significantly suppressed LPS-induced ERK1/2, p38, and JNK1/2 activation in a dose dependent manner while it had no effect on PI3k/Akt phosphorylation (Supplementary Figure 3). This observation was further confirmed by the suppressive effects of the respective MAP kinases inhibitors PD98059 (ERK-inhibitor), SB203580 (p38inhibitor), and SP600125 (JNK-inhibitor) on iNOS and COX2 expressions (Figure 3(c)). The result suggests that the anti-inflammatory effect of torilin is correlated with MAPK inactivation.

3.3. Torilin Inhibited $I-\kappa B$ Phosphorylation and NF- $\kappa B$ Activation. To further investigate the molecular mechanism involved in the torilin mediated inhibitions of inflammatory mediator and cytokine transcriptions observed in this study, we examined whether NF- $\kappa \mathrm{B}$ and/or AP-1 signaling pathways are involved. As shown in Figure 4(a), LPS stimulation markedly triggered I- $\mathrm{kB} \alpha$ phosphorylation with a concurrent decrease in total I-kB expression especially at 15 and $30 \mathrm{~min}$ LPS stimulation. Torilin pretreatment strongly and timedependently inhibited $\mathrm{I}-\mathrm{kB} \alpha$ phosphorylation and restored total I-kB depletion (Figure 4(a)). Since phosphorylation of $\mathrm{I}-\mathrm{kB} \alpha$ precedes degradation of $\mathrm{I}-\mathrm{kB} \alpha$ and subsequent release of NF- $\kappa \mathrm{B}$, we also examined the effect of torilin treatment on $\mathrm{NF}-\kappa \mathrm{B}$ activation and translocation.

3.4. Torilin Inhibits NF- $\kappa B$ and AP-1 Nuclear Translocation, DNA Binding, and Reporter Activities. Since, without entering the nucleus, NF- $\kappa \mathrm{B}$ cannot regulate transcription, we investigated effect of torilin treatment on LPS-induced NF$\kappa \mathrm{B}$ translocation, DNA binding, and reporter gene activity. The p65 and p50 nuclear translocation was analyzed from cytosolic and nuclear protein fractions at a given time interval. Torilin significantly reduced LPS-induced cytosolic p65 and p50 expressions (Figure 4(b)). The nuclear translocation of NF- $\kappa \mathrm{B}$ was markedly observed from an increased LPSinduced p65 and p50 nuclear protein expression levels that were significantly inhibited by torilin treatment (Figure 4(c)). In addition to NF- $\kappa \mathrm{B}$ activation (Supplementary Figure 4), immunoblotting revealed that LPS-induced AP-1 subunit (ATF-2 and c-jun but not c-fos) activation was also inhibited by torilin treatment (Supplementary Figure 5). 


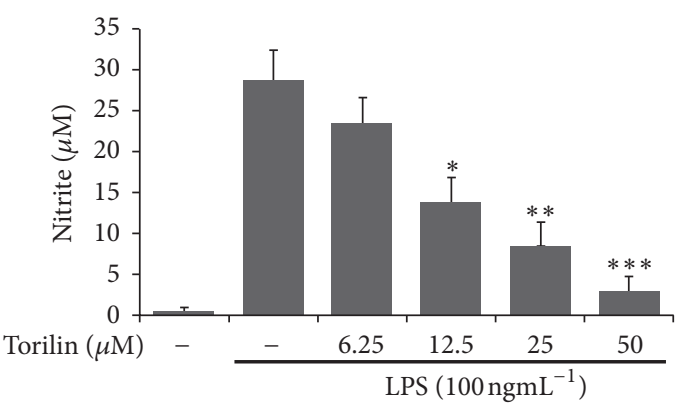

(a)

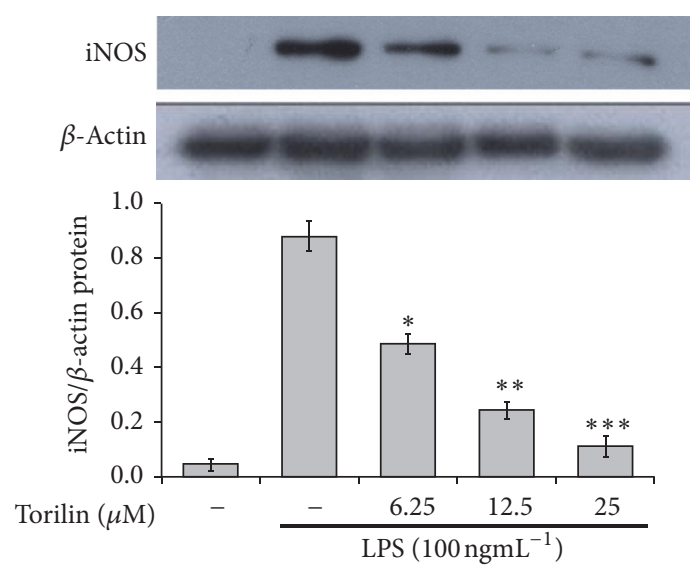

(c)

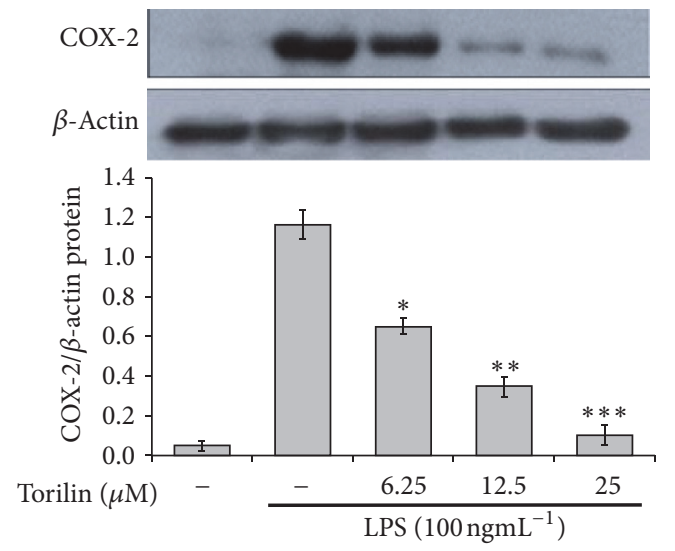

(e)

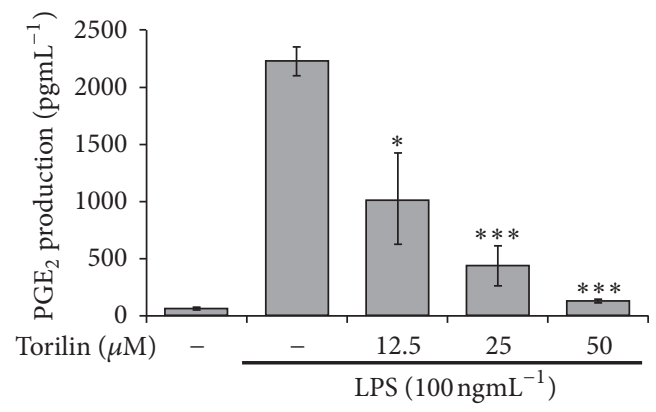

(b)

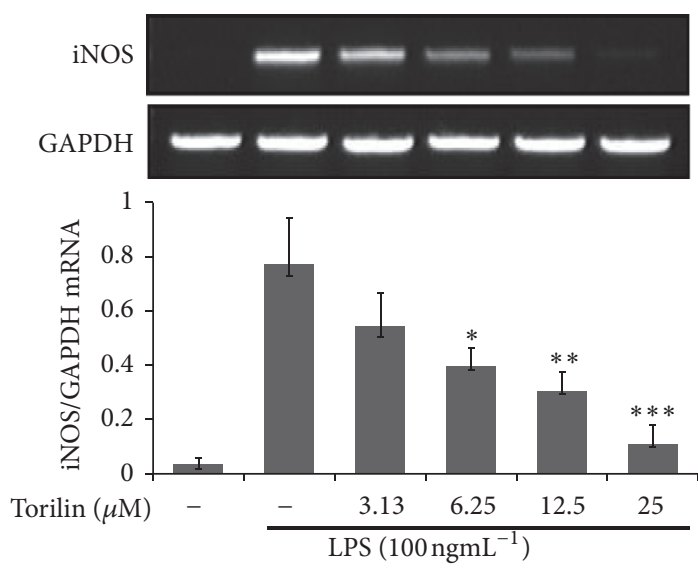

(d)

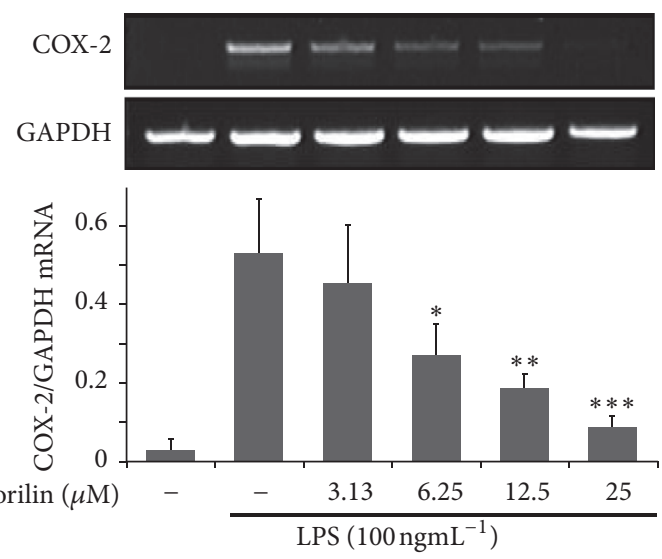

(f)

FIGURE 1: Torilin inhibits LPS-induced NO release, PGE2 secretion, and protein as well as mRNA expression of iNOS and COX-2 enzymes. RAW 246.7 macrophages were pretreated with torilin or vehicle for $30 \mathrm{~min}$ and stimulated with LPS for 18 or $24 \mathrm{~h}$. (a) Cell culture supernatants were analyzed for nitrite release, as a measure of NO production. (b) $\mathrm{PGE}_{2}$ secretion in culture media was analyzed in torilin treated RAW cells as described in Materials and Methods. After $24 \mathrm{~h}$ of stimulation for protein expression (c) and $18 \mathrm{~h}$ of stimulation for mRNA expression (d) were depicted, respectively. Again, COX-2 protein (e) and mRNA (f) were determined by western blot and RT-PCR, respectively. GAPDH and $\beta$-actin were used as controls for mRNA and protein loading, respectively. Images are representative of 3 or 4 independent experiments. Values in bar graphs are means \pm SE of at least 4 independent experiments performed in triplicate. Significance was determined using Student's $t$-test versus the control group. ${ }^{*} P<0.05,{ }^{* *} P<0.01,{ }^{* * *} P<0.001$ versus LPS.

To examine whether torilin attenuates LPS-induced NF$\mathrm{kB}$ and/or AP-1 DNA binding, we conducted EMSA analyses. As shown in Figures 5(a) and 5(b), torilin at the doses of 25 and $50 \mu \mathrm{M}$ demonstrated a selective reduction in NF- $\kappa \mathrm{B}$ and AP-1 DNA binding. To further investigate whether torilin attenuates promoter activities of the indicated transcription factors, we tested luciferase reporter gene transcription. Incubation of transfected RAW 264.7 cells with LPS for $6 \mathrm{~h}$ 


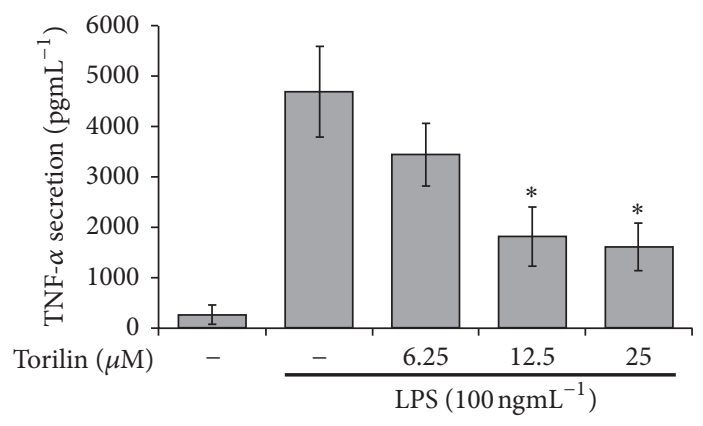

(a)

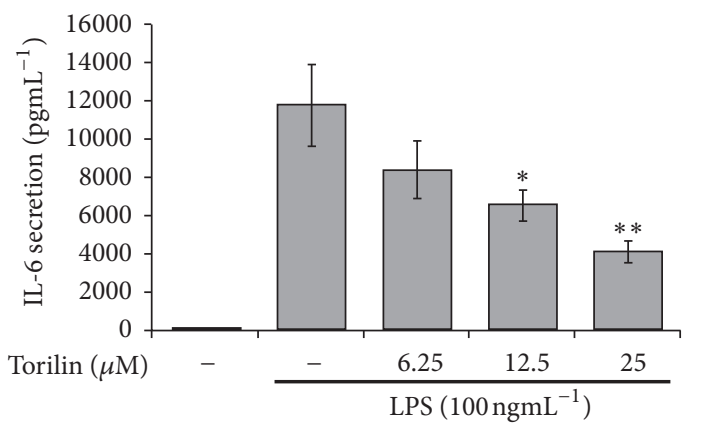

(c)

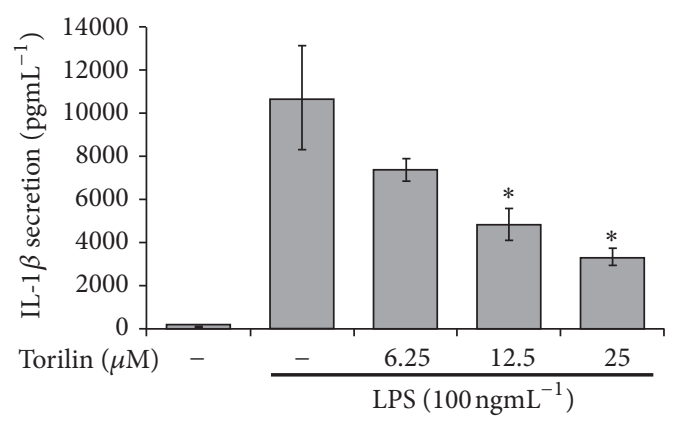

(b)

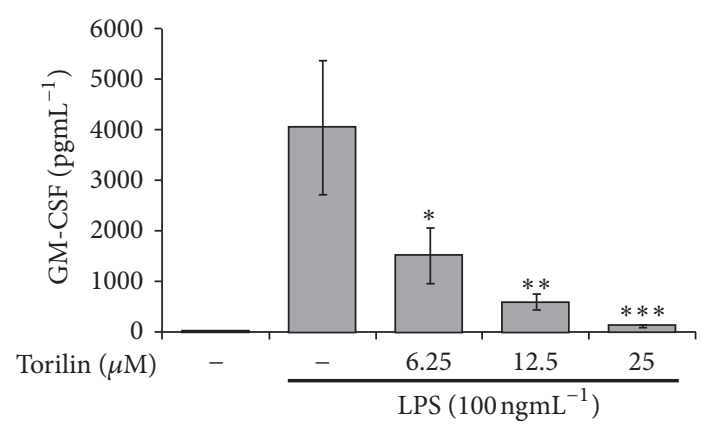

(d)

FIGURE 2: Torilin pretreatment reduces LPS-induced proinflammatory cytokine secretions into the culture media. RAW 264.7 cells were pretreated with torilin or vehicle for 30 min and stimulated with LPS for 24 h. TNF- $\alpha$ (a), IL-1 $\beta$ (b), IL-6 (c), and GM-CSF (d) were determined using ELISA. Each bar graph represents mean \pm (SE) for four independent experiments. Significance was determined using Student's $t$-test. ${ }^{*} P<0.05,{ }^{* *} P<0.01,{ }^{* * *} P<0.001$.

increased luciferase activity. However, the increased NF- $\kappa \mathrm{B}$ and AP-1 reporter gene activities were suppressed in torilinsensitive manner (Figures 5(c) and 5(d)), suggesting that the compound's inhibitory effect is associated with reduced NF$\mathrm{kB}-$ and AP-1-DNA binding and promoter activities.

3.5. Torilin Suppressed I $\kappa B$ Kinase- $\alpha / \beta(I K K \alpha / \beta)$ Activation. Since activation of NF- $\kappa B$ is induced by a cascade of signaling events leading to the activation of IKK complex, which in turn phosphorylates $\mathrm{I} \kappa \mathrm{B}[28,29]$, we determined torilin influence on LPS-induced IKK $\alpha / \beta$ activation. In parallel with its inhibition on LPS-induced phosphorylation and $\mathrm{I} \kappa \mathrm{B} \alpha$ degradation (Figure 4(a)), torilin suppressed IKK $\alpha / \beta$ activation at the indicated time course (Figure 6(a)), suggesting that LPS-induced kinase activity may be impaired by the test compound that ultimately leads to an inhibition in IKK-mediated $\mathrm{I} \kappa \mathrm{B} \alpha$ phosphorylation and NF- $\kappa \mathrm{B}$ regulated inflammatory response. However, it is worth noticing that $\mathrm{NF}-\kappa \mathrm{B}$ is not the only pathway that could be modified by torilin because phosphorylation of IKK $\alpha / \beta$ is also regulated by other upstream factors such as MAPKs, including ERK, $\mathrm{JNK}$, and p38. We, indeed, affirmed that torilin markedly suppressed the upregulation of these kinases after LPS stimulation (Figures 3(a) and 3(b)), suggesting that torilin affects some upstream targets as they inhibit the NF-kB and MAPK pathways simultaneously and further potentiate the suppression of inflammatory responses.
3.6. Torilin Inhibits LPS-Induced TAK1 Activation and Multiple Components of Downstream Signaling Pathway. Since our data showed that torilin affects both IKK $\alpha / \beta$ and MAPK downstream pathways, we thought that its inhibitory effect might involve upstream common pathway that lies between TLR4 and MAP3K complexes. Interestingly, immunoblotting analysis revealed that while torilin did not affect LPSstimulated activation of MyD88, IRAK1, and TRAF6 (data not shown), it markedly inhibited TAK1, MKK4, and IKK $\alpha / \beta$ activation (Figures 6(a) and 6(b)). Since Shim et al. found that TNFR1, IL-1R, TLR3, and TLR4-mediated NF- $\kappa$ B and AP-1 activation are severely impaired in TAK1 deficient cells, but not in TAK1-binding protein 1 and 2 (TAB1/2) deficient cells [30], and since torilin did not affect MyD88, IRAK1, and TRAF6 downstream of TLR4 but suppressed the signaling effects thereafter we further examined the test compound's effect at the level of MAP3K complexes. TAK1 was immunoprecipitated from LPS-stimulated untreated cells and from cells treated with torilin, as indicated in Figure 6(d). The immunoprecipitates were separated on SDS-PAGE, and the membrane was blotted with an antibody that recognizes $\mathrm{p}-$ TAK1, TAK1, p-MKK4, MKK4, p-IKK $\alpha / \beta$, and IKK $\alpha / \beta$. TAK1 precipitation increased LPS-induced p-TAK1 activation and brought down the basal TAK1 protein expression, the event of which was reversed by torilin treatment (Figure $6(\mathrm{~d})$ ). We were also able to detect torilin mediated inhibition of MKK4 and IKK $\alpha / \beta$ phosphorylation while the 


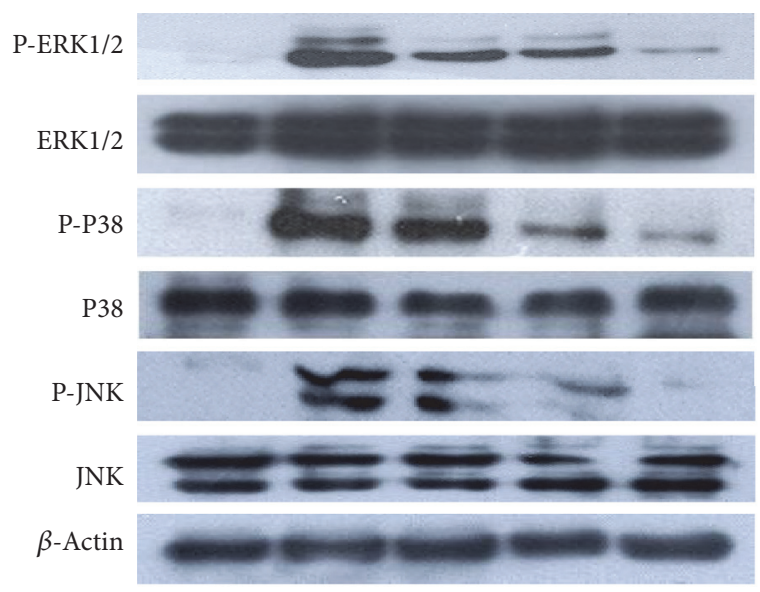

(a)

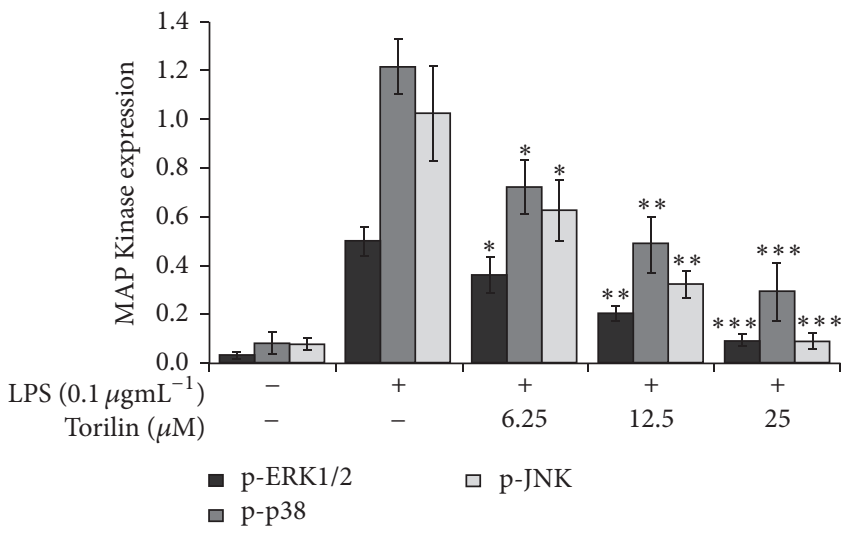

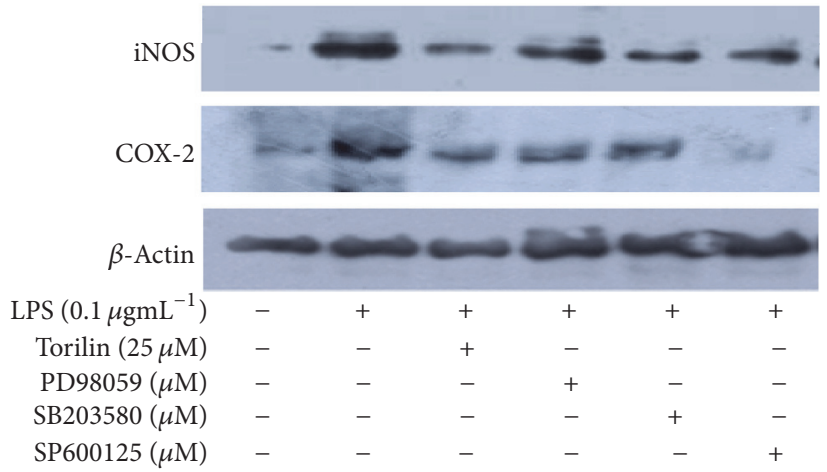

(c)

(b)

FIGURE 3: Effect of torilin on mitogen activated protein kinase (MAPK) activation. LPS-stimulated RAW 264.7 macrophages were treated with vehicle or torilin $(6.25-25 \mu \mathrm{M})$ and stimulated with LPS for the indicated periods of time. Total protein was subjected to western blot analyses using total and phospho-anti-RK1/2, p38 ${ }^{\mathrm{MAPK}}$, and JNK1/2 antibodies. Torilin suppressed phosphorylation of the three MAPKs (a and b). Cells were further pretreated with vehicle or PD98059 $(30 \mu \mathrm{M})$, ERK1/2 inhibitor, SB203580 (10 $\mu \mathrm{M})$, p38 ${ }^{\mathrm{MAPK}}$ inhibitor, or SP600125 $(10 \mu \mathrm{M}), \mathrm{JNK} 1 / 2$ inhibitor, with torilin and stimulated with $100 \mathrm{ngmL}^{-1}$ LPS as indicated in (c). Significance was determined using Student's $t$-test versus the control group. Images are representative of 3 or 4 independent experiments. Values in bar graphs are means \pm SE of at least 4 independent experiments performed in triplicate. ${ }^{*} P<0.05,{ }^{* *} P<0.01,{ }^{* * *} P<0.001$ versus LPS.

basal activities of these kinases were not affected in torilin treated and TAK1 precipitated lysates. Interestingly, torilin further inhabited LPS-stimulated TAK1 kinase activation (Figure 6(c)), suggesting torilin's upstream inhibitory effect at the level of MAP3k complex early in the signaling event through the inhibition of TAK1 activation with a marked limitation of LPS-induced NF- $\kappa$ B and MAPKs stimulation.

\section{Discussion}

The promotion of inflammatory conditions and the initiation of the innate immune response require the release of many special effector proteins, the synthesis of which is transcriptionally regulated by inducible transcription factors that bind to the promoter regions of their respective genes. Such effectors (mediators of inflammation) include iNOS, COX-2, and cytokines (TNF- $\alpha$, IL-1, IL-6, and GM-CSF). NF$\kappa \mathrm{B}$ and $\mathrm{AP} 1$ are among the principal inducible transcription factors that play pivotal roles in innate immune response [31] and chronic inflammatory conditions such as rheumatoid arthritis [32]. Recently, the demand for natural products limiting induction of inflammatory mediators with minimal side effects is growing.

For decades, numerous studies have been reported to support the promise that natural products and phytochemicals could be protective against the risk of various types of inflammation and a large body of evidence indicated the antiinflammatory effects of these compounds in terms of their action against kinases, adaptor proteins, the transcription factors, such as NF- $\kappa \mathrm{B}$ and $\mathrm{AP}-1$, and the genes regulated by such transcription factors $[8,9,11,33]$.

Sesquiterpenes, plant-derived compounds, are reported to modulate NF- $\kappa \mathrm{B}$ and AP-1 transduction pathways and inhibit inflammatory mediators and inflammatory processes that help alleviate the symptoms of inflammatory diseases including arthritis $[9,11]$. Since, torilin, a sesquiterpene, 


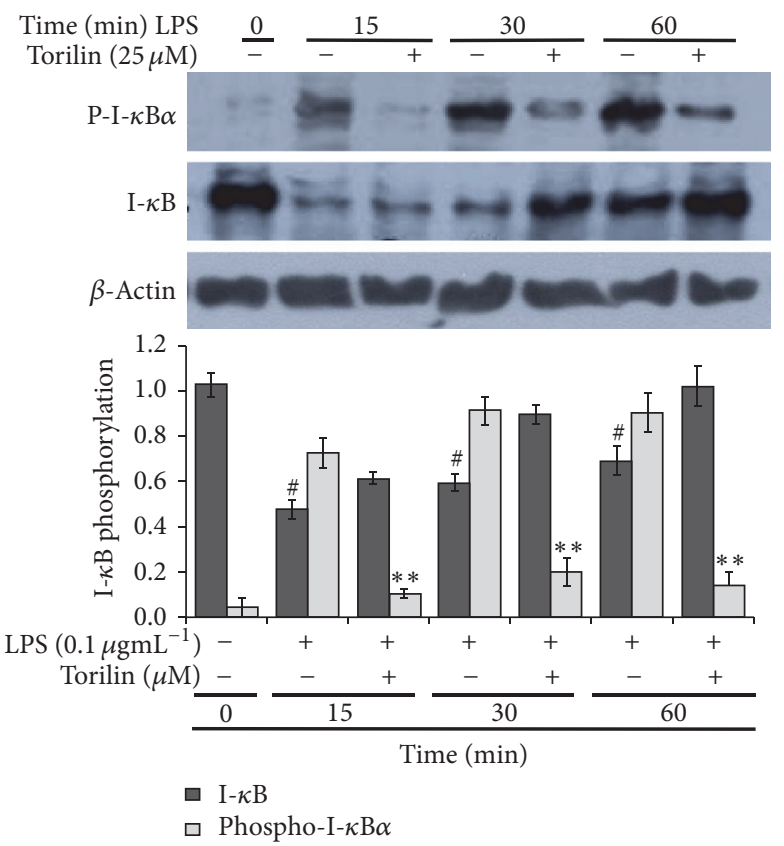

(a)

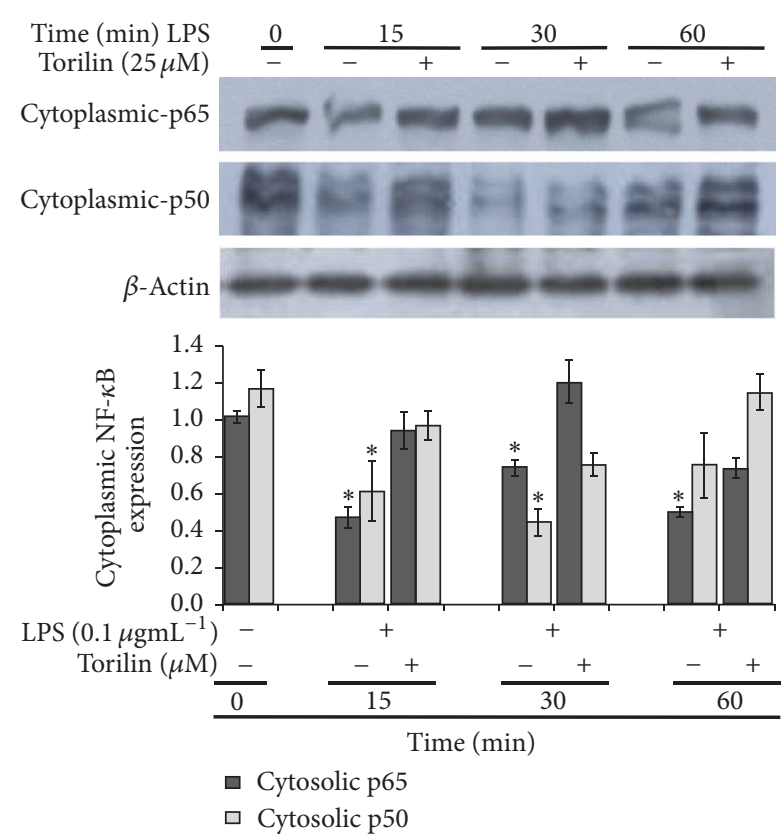

(b)

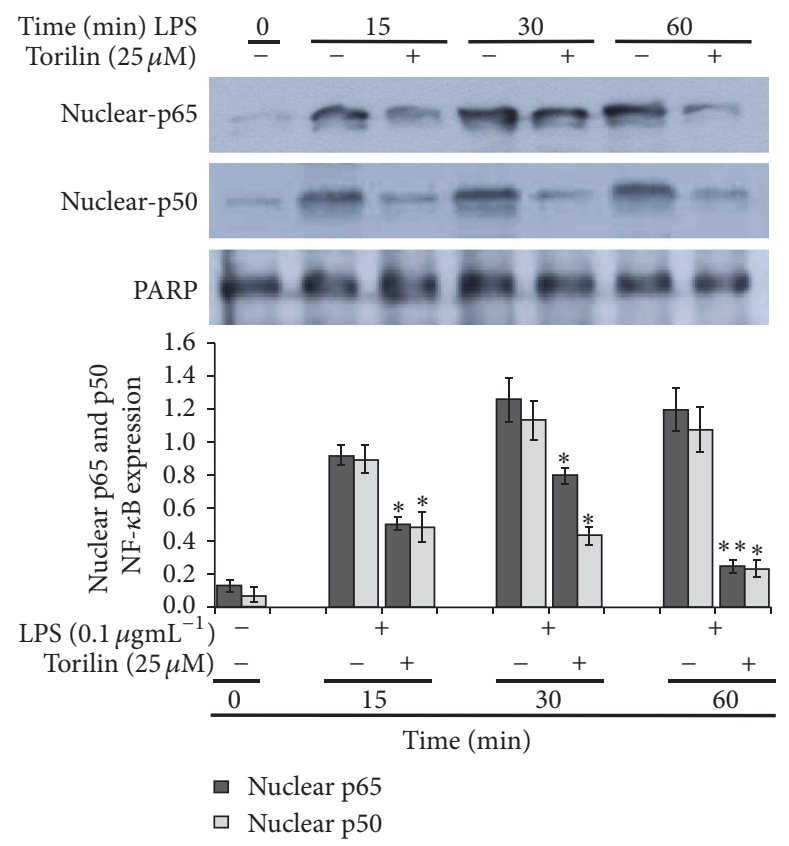

(c)

FIGURE 4: Torilin restores I- $\kappa \mathrm{B} \alpha$ phosphorylation and degradation; thereby it inhibits p65-NF- $\kappa$ B nuclear translocation. (a) RAW 264.7 cells were pretreated with the indicated concentrations of torilin for $30 \mathrm{~min}$ and incubated with LPS (100 ng/ml) for (15-60 min) time course and then assayed for the phosphorylation and degradation of I- $\kappa \mathrm{B} \alpha$ and nuclear translocation of p65 by western immunoblot analysis as described under Materials and Methods. (b and c) RAW macrophages were treated with LPS $\left(100 \mathrm{ngmL}^{-1}\right.$ ) and $25 \mu \mathrm{M}$ torilin, respectively, for the indicated time course before cytoplasmic and nuclear protein fractions were subjected to western blot analyses for p65 (upper panel) and p50 (middle panel) of cytoplasmic (b) and nuclear (c) proteins, respectively. $\beta$-Actin and ploy(ADP-ribose) polymerase (PARP) were used as a control for the cytoplasmic and nuclear protein loading, respectively. Images are representative of 3 or 4 independent experiments. Values in bar graphs are means \pm SE of at least 4 independent experiments performed in triplicate. Significance was determined using Student's $t$-test. ${ }^{*} P<0.05,{ }^{* *} P<0.01,{ }^{* * *} P<0.001$. ${ }^{*}$ The significance of IkB degradation upon LPS activation associated with p-IkB phosphorylation in comparison with torilin treated group as analysed from western blot band size. 


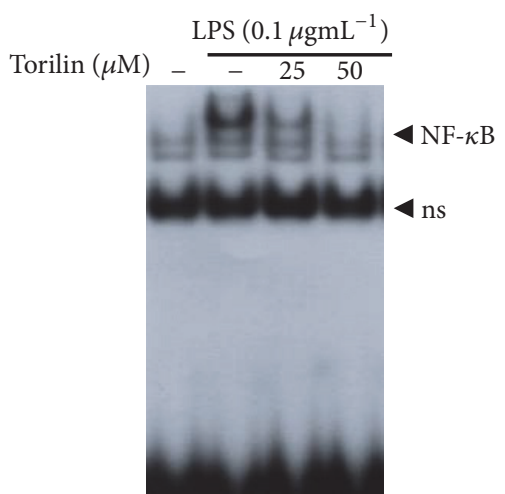

(a)

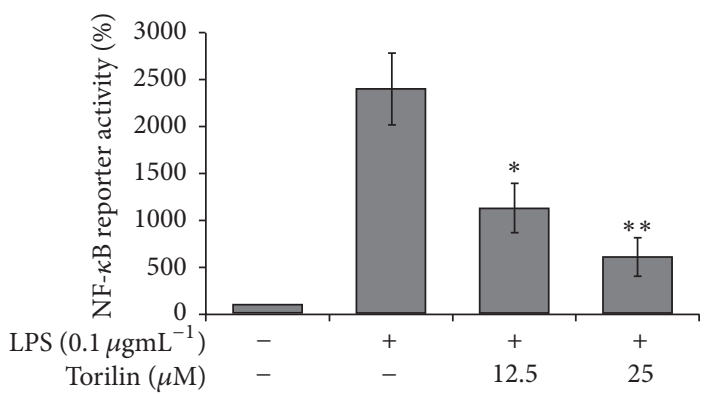

(c)

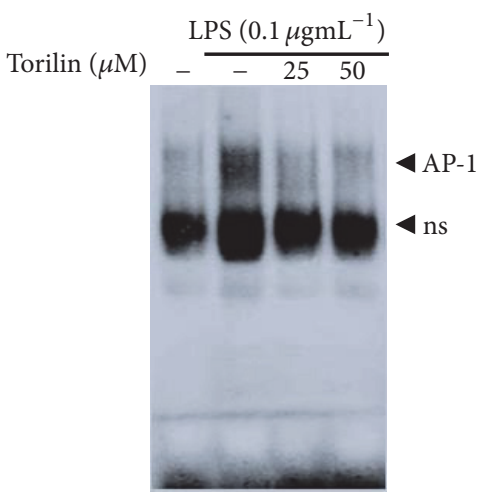

(b)

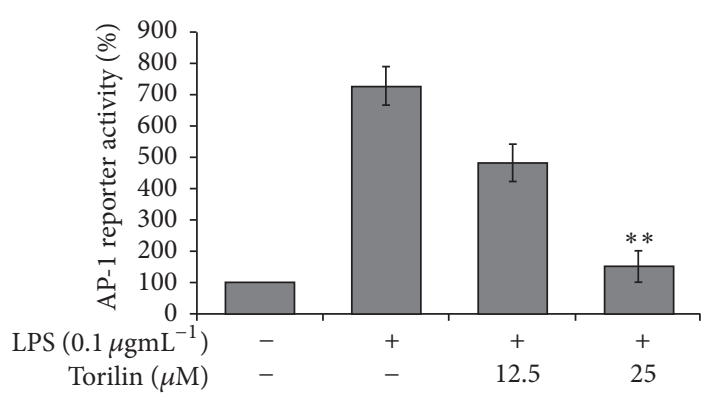

(d)

FIGURE 5: Torilin arrests AP-1 and NF- $\kappa$ B DNA binding and reporter gene expression in LPS-stimulated RAW 264.7 cells. RAW macrophages were treated with vehicle or torilin (as indicated) and stimulated with LPS for 45 min before nuclear protein was isolated. DNA binding was analyzed using specific $\gamma 32 \mathrm{P}-$ labeled oligonucleotide probes for NF- $\kappa \mathrm{B}$ (a) or AP-1 (b). Specificity was demonstrated by coincubation with a 25 -fold excess of unlabeled specific probe of NF- $\kappa$ B and AP-1 for competition. Cells were transiently transfected with NF- $\kappa$ B (c) or AP-1 (d), plasmids treated with the indicated concentrations of torilin and LPS $\left(100 \mathrm{ngmL}^{-1}\right)$ for $6 \mathrm{~h}$ and assayed for CAT expression using a CAT enzyme-linked immunosorbent assay kit. Each column shows the mean \pm SEM of quadruplicate determinations. Luciferase activity was normalized to $\beta$-galactosidase activity. Images are representative of 3 independent experiments. ${ }^{*} P<0.05,{ }^{* *} P<0.01$, as compared with vehicle.

has been shown to possess anti-inflammatory activities in vitro and in vivo [24, 25], we, using mouse model of rheumatic arthritis, have previously reported that torilin modifies inflammatory cell and cytokine imbalances with the attenuation of the severity of arthritis [26]. We, here further, report the in vitro inhibitory effect of torilin in LPS-inducible inflammatory mediators and proinflammatory cytokines and propose the underlying mechanism of action in LPS-stimulated RAW 264.7 cells. The mediators of inflammation protein secretion and mRNA expressions revealed that torilin effectively blocked the LPS-stimulated NO generation, PGE2 synthesis, and iNOS and COX-2 protein and mRNA expressions, respectively. In addition, LPS-activated TNF- $\alpha$, IL-1 $\beta$, IL- 6 , and GM-CSF protein secretions and gene expressions are markedly inhibited by torilin treatment, suggesting that the test compound's widespectrum effect on inflammatory mediators might arise from its influence on the upstream common signaling pathway.

This study examined the involvement of MAPKs as a molecular target for torilin mediated inhibition of LPS-induced inflammatory mediators and proinflammatory cytokine inductions. All the three MAPKs, that is, ERK1/2, $\mathrm{p} 38^{\mathrm{MAPK}}$ and JNK1/2, were markedly suppressed by torilin pretreatment. Using the selective MAPK inhibitors, PD98059, SB203580, and SP600125, we further confirmed that blockade of the indicated MAPK activities by their respective inhibitors suppressed iNOS and COX-2 expressions. Moreover, torilin arrested AP1 transactivation and its subunits (ATF2, c-jun, and c-fos) phosphorylation. This observation suggests that the inhibitory effect of torilin on iNOS and COX-2 induction was at least partly regulated via MAPKs mediated AP1 transactivation. In agreement with our data, several lines of evidence documented the essential roles of MAPKs in regulating LPS-induced inflammatory responses. MAPK cascades mediate LPS-stimulated induction of COX2 and IL-1 $\beta$ in RAW264 macrophages [34]. Likewise, ERK and p38 subgroups of MAPKs regulate iNOS and TNF$\alpha$ gene expressions in endotoxin-stimulated glial cells [35], and $\mathrm{p} 38^{\mathrm{MAPK}}$ also plays role in IL-1 $\beta$ transcription [36]. Hwang et al. have reported blockade of ERK1/2 and p $38^{\mathrm{MAPK}}$ activities by PD 98059 and SB203580, respectively, resulting in partial suppression of LPS-induced COX-2 expression [37], and monocytes treated with LPS in the presence of MEK inhibitor U0126 failed to release cytokines and PGE2 [38], supporting the notion that the MAPK pathway is critical for inflammatory response and torilin with the inhibitory 


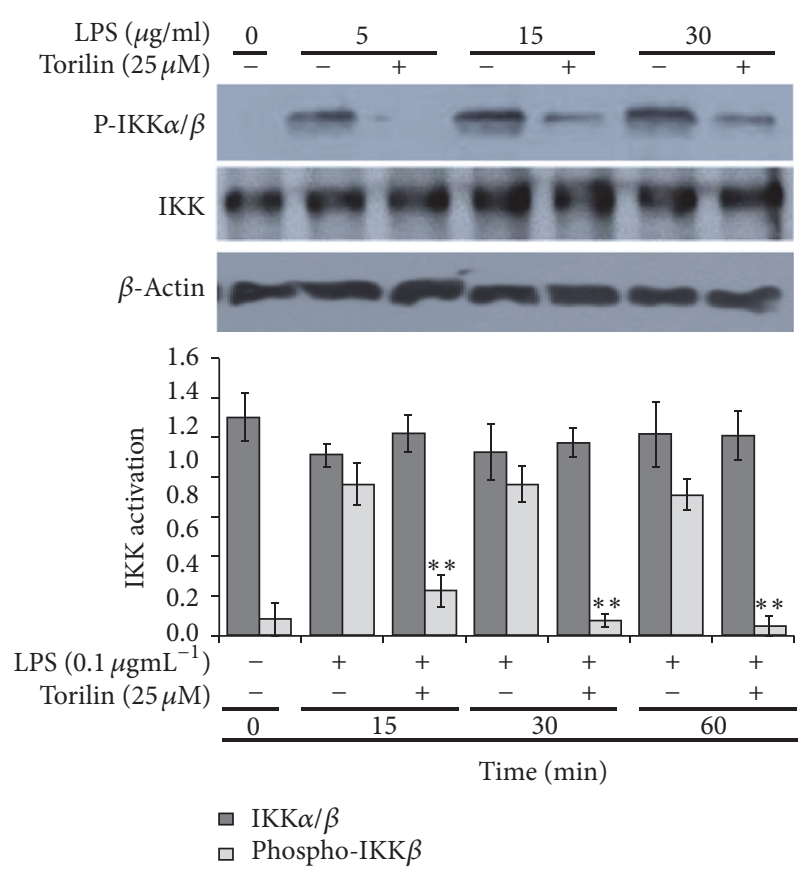

(a)

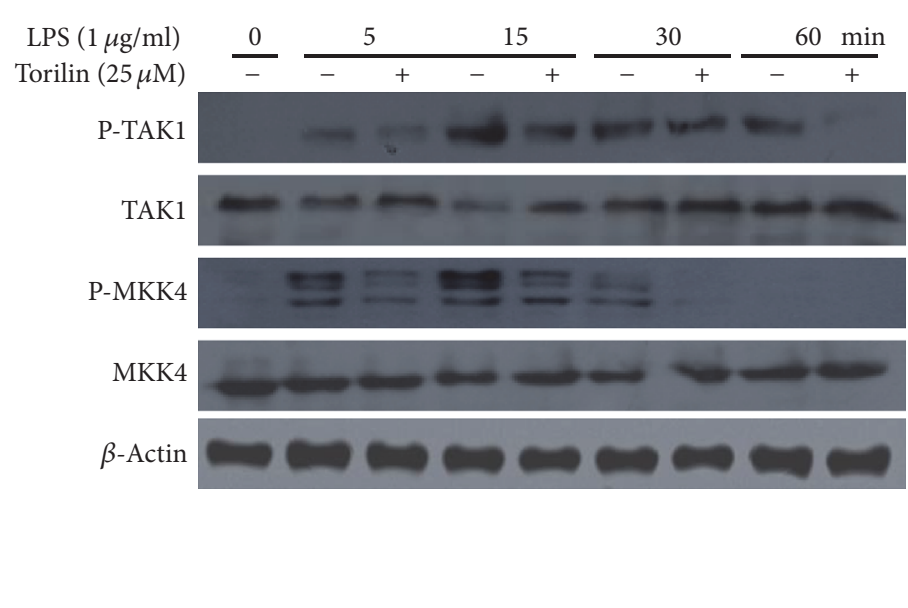

(b)

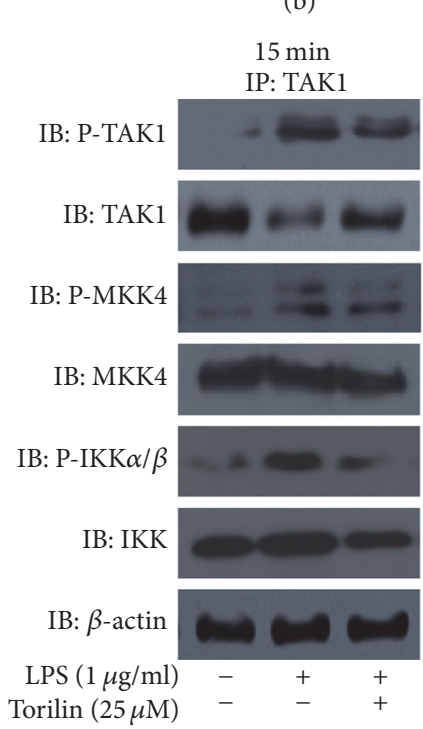

(d)

FIGURE 6: Torilin suppresses LPS-induced IKK and MAP3K complex activation and inhibits the TAK1 interaction with the components of MAPK and NF- $\kappa$ B signaling pathways. RAW macrophage cells were incubated with torilin or vehicle for 30 min and then stimulated with LPS as indicated in the figures. (a) Lysates from torilin or vehicle treated-cells were immunoblotted to detect the activation status of IKK. (b) Immunoblots depicting the time dependent effects of torilin in TAK1, MKK4, and IKK phosphorylation. (c) The kinase activity of the TAK1 was determined after immunoprecipitates were resuspended in kinase buffer and assayed for kinase activity as described in Materials and Methods. (d) Cell lysates were immunoprecipitated by incubating overnight with anti-TAK1 antibody and then incubated with protein A-Sepharose (PAS) for $4 \mathrm{~h}$ at $4^{\circ} \mathrm{C}$. Precipitated proteins were separated by SDS-PAGE and immunoblotted to detect P-TAK1, TAK1, p-MKK4, MKK4, $\mathrm{p}-\mathrm{IKK} \alpha / \beta, \mathrm{IKK}$, and $\beta$-actin. Equivalent protein loading was verified by reprobing for the respective total antibodies and $\beta$-actin. Images are representative of 4 or more independent experiments. Values in bar graphs are means \pm SE of at least 4 separate experiments performed in triplicate. ${ }^{*} P<0.05,{ }^{* *} P<0.01$ versus control. 
potential of this pathway could be a better candidate against inflammation.

In agreement with our study, an isolated report indicated anti-inflammatory effect of torilin in BV2 cells [25]. The authors reported that torilin inhibits iNOS, COX-2, PGE2, and IL- $1 \beta$ activation and they suggested that torilin mediated inhibition of ERK or p38 but not JNK activation is one of the possible mechanisms underlying its inhibitory action on iNOS expression and NO production [25]. The discrepancy on JNK activation between the reported study and the present investigation may be due to the difference in cells used in the respective studies. In line with this, negative regulation of p38 and IKK activation by TGF- $\beta$-activated kinase 1 (TAK1) was observed in a cell type-specific manner [39]. However, torilin action against a wide range of LPS-induced inflammatory mediators, MAPKs, and transcription factors suggests that upstream pathway early signaling event may be affected.

Since a critical step in LPS-induced NF- $\kappa$ B nuclear accumulation and transcriptional activity is p65 and p50 dissociation from $\mathrm{I} \kappa \mathrm{B}$ protein, this study investigated effect of torilin treatment in $\mathrm{I} \kappa \mathrm{B}$ and its kinase activity. Interestingly, we found that torilin inhibited LPS-induced IKK $\alpha / \beta$ activation, $\operatorname{IkB} \alpha$ phosphorylation, and decreased p65 and p50 nuclear translocation. In line with our findings, other sesquiterpenes have been shown to inhibit activation of NF$\kappa \mathrm{B}$ by preventing the degradation of $\mathrm{I}-\kappa \mathrm{B}-\alpha$ and $\mathrm{I}-\kappa \mathrm{B}-\beta$ [13], inhibiting $\mathrm{NF}-\kappa \mathrm{B}$ activation [40], and suppressing iNOS and COX-2 expression through the inactivation of NF-kB [41] or by directly binding to and inhibiting I- $\kappa \mathrm{B}$ kinase $[14,15]$.

We, in the present study, observed that torilin pretreatment suppressed MAPK and IKK mediated I- $\kappa$ B phosphorylation, NF- $\kappa \mathrm{B}$ and AP1 nuclear translocation, DNA binding, and reporter transcriptional activation reflecting the ability of torilin to inhibit NF- $\kappa \mathrm{B}$ and AP-1 dependent inflammatory mediators and proinflammatory cytokine transcriptions. Such a strong effect of torilin on both IKK and MAPK activation in the present study suggests its role on early common upstream signaling events. However, torilin did not affect MyD88, IRAK1, and TRAF6 downstream of TLR4 but suppressed the signaling effects thereafter at the level of MAP3K complexes. Interestingly, torilin inhibited TAK1 kinase activation and phosphorylation with subsequent TAK1 mediated activation of kinases such as the I- $\kappa$ B kinase and MAP kinases, which in turn modulate the transcriptional activities of the NF-kB and AP-1 families, respectively. However, the molecular mechanisms responsible for torilin mediated TAK1 inactivation remains to be addressed.

Since TAK1, a member of the MAPKKK family, is thought to be a key modulator of adaptive and innate immunity that mediates inducible transcription factors NF- $\kappa \mathrm{B}$ and $\mathrm{AP}-$ 1 and, therefore, plays a crucial role in regulating the genes that mediate inflammation $[30,42]$, we thought that natural compounds such as torilin that target TAK1 activation may be an attractive strategy to treat inflammatory responses. The present study together with our previous report [26] indicated that torilin plays a crucial role against TAK1 mediated cellular response to LPS-induced and collagen-induced [26] inflammatory stimuli. TAK1 is a critical integration check point for innate and adapted immune responses upstream of
MAP kinase and I- $\mathrm{kB}$ kinase pathways $[3,43]$. In line with this study, TAK1-deficient cells failed to activate NF- $\kappa$ B and MAP kinases in response to IL-1 $\beta$, TNF, and TLR ligands [30]. In addition to its role in innate immunity, recent studies have defined an essential role of TAK1 in T cell receptor- and B cell receptor-induced activation of NF-kB and in the survival and development of immune cells, including mature B cells and $\mathrm{T}$ cells $[3,43-45]$. In B cells, TAK1 is reported to be required for $B$ cell development and NF-kB and MAPK activation induced by cytokines, TLR ligands, and BCR stimuli $[3,45]$.

In conclusion, we demonstrate that torilin arrested LPSinduced TAK1 kinase activation with a subsequent suppression in IKK-mediated I- $\kappa$ B phosphorylation NF- $\kappa$ B translocation. In addition, it attenuated TAK1 mediated MAPKs activation and AP1 transactivation. Together, the data led to suppression of NF- $\kappa \mathrm{B}$ and $\mathrm{AP}-1$ regulated inflammatory mediator and cytokine expressions, suggesting the test compound's potential as a candidate anti-inflammatory agent.

\section{Abbreviations}

$\begin{array}{ll}\text { COX-2: } & \text { Cyclooxygenase-2 } \\ \text { GM-CSF: } & \begin{array}{l}\text { Granulocyte-macrophage colony } \\ \text { stimulating factor }\end{array} \\ \text { IKK or I } \kappa \text { B kinase: } & \begin{array}{l}\text { Inhibitory nuclear factor kappa-B } \\ \text { kinase }\end{array} \\ \text { IL-1 } \beta \text { : } & \text { Interleukin-1 } \beta \\ \text { IL-6: } & \text { Interleukin-6 } \\ \text { iNOS: } & \text { Inducible nitric oxide synthase } \\ \text { MAPKs: } & \text { Mitogen activated protein kinases } \\ \text { NF- } \kappa \text { B: } & \text { Nuclear factor kappa-B } \\ \text { NO: } & \text { Nitric oxide } \\ \text { PGE }: & \text { Prostaglandin } \mathrm{E}_{2} \\ \text { PI3K: } & \text { Phosphatidylinositol 3-phosphate } \\ \text { PKB/Akt: } & \text { Protein kinase B } \\ \text { RT-PCR: } & \text { Reverse transcription PCR } \\ \text { TNF- } \alpha: & \text { Tumor necrosis factor- } \alpha \\ \text { TAK1: } & \text { TGF } \beta \text {-activated kinase } 1 \\ \text { TAB1/2: } & \text { TGF } \beta \text {-activated kinase } 1 \text { bind } \\ & \text { proteins } 1 \text { and } 2 .\end{array}$

\section{Competing Interests}

The authors declare no conflict of interests.

\section{Acknowledgments}

This research was supported by the National Research Foundation of Korea Grant funded by the Korean government (Grant no. 2015R1D1A1A09057204) and by Research Base Construction Fund Support Program funded by Chonbuk National University in 2016.

\section{References}

[1] S. Akira and K. Takeda, "Toll-like receptor signalling," Nature Reviews Immunology, vol. 4, no. 7, pp. 499-511, 2004.

[2] Z. J. Chen, "Ubiquitin signalling in the NF- $\kappa$ B pathway," Nature Cell Biology, vol. 7, no. 8, pp. 758-765, 2005. 
[3] S. Sato, H. Sanjo, K. Takeda et al., "Essential function for the kinase TAK1 in innate and adaptive immune responses," Nature Immunology, vol. 6, no. 11, pp. 1087-1095, 2005.

[4] M. Guha and N. Mackman, "LPS induction of gene expression in human monocytes," Cellular Signalling, vol. 13, no. 2, pp. 8594, 2001.

[5] N. J. Gay and M. Gangloff, "Structure and function of toll receptors and their ligands," Annual Review of Biochemistry, vol. 76, no. 1, pp. 141-145, 2007.

[6] G. Bonizzi and M. Karin, "The two NF- $\kappa$ B activation pathways and their role in innate and adaptive immunity," Trends in Immunology, vol. 25, no. 6, pp. 280-288, 2004.

[7] M. Endale, S.-C. Park, S. Kim et al., "Quercetin disrupts tyrosine-phosphorylated phosphatidylinositol 3-kinase and myeloid differentiation factor- 88 association, and inhibits MAPK/ AP-1 and IKK/NF- $\kappa$ B-induced inflammatory mediators production in RAW 264.7 cells," Immunobiology, vol. 218, no. 12, pp. 1452-1467, 2013.

[8] A. Deorukhkar, S. Krishnan, G. Sethi, and B. B. Aggarwal, "Back to basics: how natural products can provide the basis for new therapeutics," Expert Opinion on Investigational Drugs, vol. 16, no. 11, pp. 1753-1773, 2007.

[9] A. Salminen, M. Lehtonen, T. Suuronen, K. Kaarniranta, and J. Huuskonen, "Terpenoids: natural inhibitors of NF- $\kappa$ B signaling with anti-inflammatory and anticancer potential," Cellular and Molecular Life Sciences, vol. 65, no. 19, pp. 2979-2999, 2008.

[10] A. Kumar, Y. Takada, A. M. Boriek, and B. B. Aggarwal, "Nuclear factor- $\kappa \mathrm{B}$ : its role in health and disease," Journal of Molecular Medicine, vol. 82, no. 7, pp. 434-448, 2004.

[11] P. Bremner and M. Heinrich, "Natural products as targeted modulators of the nuclear factor- $\kappa \mathrm{B}$ pathway," Journal of Pharmacy and Pharmacology, vol. 54, no. 4, pp. 453-472, 2002.

[12] T. Kawai and S. Akira, "Signaling to NF- $\kappa$ B by Toll-like receptors," Trends in Molecular Medicine, vol. 13, no. 11, pp. 460-469, 2007.

[13] S. P. Hehner, M. Heinrich, P. M. Bork et al., "Sesquiterpene lactones specifically inhibit activation of NF- $\kappa$ B by preventing the degradation of $\mathrm{I} \kappa \mathrm{B}-\alpha$ and I $\kappa \mathrm{B}-\beta$," Journal of Biological Chemistry, vol. 273, no. 3, pp. 1288-1297, 1998.

[14] S. P. Hehner, T. G. Hofmann, W. Dröge, and M. L. Schmitz, "The antiinflammatory sesquiterpene lactone parthenolide inhibits NF- $\kappa$ b by targeting the I $\kappa \mathrm{B}$ kinase complex," The Journal of Immunology, vol. 163, no. 10, pp. 5617-5623, 1999.

[15] B. H. B. Kwok, B. Koh, M. I. Ndubuisi, M. Elofsson, and C. M. Crews, "The anti-inflammatory natural product parthenolide from the medicinal herb Feverfew directly binds to and inhibits I $\kappa$ B kinase," Chemistry \& Biology, vol. 8, no. 8, pp. 759-766, 2001.

[16] A. J. García-Piñeres, V. Castro, G. Mora et al., "Cysteine 38 in p65/NF- $\kappa$ B plays a crucial role in DNA binding inhibition by sesquiterpene lactones," The Journal of Biological Chemistry, vol. 276, no. 43, pp. 39713-39720, 2001.

[17] B. Siedle, A. J. García-Piñeres, R. Murillo et al., "Quantitative structure-activity relationship of sesquiterpene lactones as inhibitors of the transcription factor NF- $\kappa \mathrm{B}$," Journal of Medicinal Chemistry, vol. 47, no. 24, pp. 6042-6054, 2004.

[18] I.-K. Lee, J.-H. Lee, E. I. Hwang, and B.-S. Yun, "New guaiane sesquiterpenes from the fruits of Torilis japonica," Chemical and Pharmaceutical Bulletin, vol. 56, no. 10, pp. 1483-1485, 2008.

[19] H. J. Youn, J. Lakritz, G. E. Rottinghaus et al., "Anti-protozoal efficacy of high performance liquid chromatography fractions of Torilis japonica and Sophora flavescens extracts on Neospora caninum and Toxoplasma gondii," Veterinary Parasitology, vol. 125, no. 3-4, pp. 409-414, 2004.

[20] W.-I. Cho, J.-B. Choi, K. Lee, M.-S. Chung, and Y.-R. Pyun, "Antimicrobial activity of torilin isolated from Torilis japonica fruit against Bacillus subtilis," Journal of Food Science, vol. 73, no. 2, pp. M37-M46, 2008.

[21] S. E. Kim, Y. H. Kim, Y. C. Kim, and J. J. Lee, “Torilin, a sesquiterpene from torilis japonica, reverses multidrug-resistance in cancer cells," Planta Medica, vol. 64, no. 4, pp. 332-334, 1998.

[22] M. S. Kim, Y. M. Lee, E.-J. Moon, S. E. Kim, J. J. Lee, and K.-W. Kim, "Anti-angiogenic activity of torilin, a sesquiterpene compound isolated from Torilis japonica," International Journal of Cancer, vol. 87, no. 2, pp. 269-275, 2000.

[23] M. S. Kim, J. H. Baek, M. T. Park et al., "Anti-invasive activity of torilin, a sesquiterpene compound isolated from Torilis japonica," Oncology Reports, vol. 8, no. 2, pp. 359-364, 2001.

[24] E. B. Lee, S. I. Cho, S. S. Kang, K. R. Kim, and T. H. Kim, "Isolation of torilin from Torilis japonica fruit and its analgesic and anti-inflammatory activities," Korean Journal of Pharmacognosy, vol. 30, no. 2, pp. 137-144, 1999.

[25] Y. Choi, M. K. Lee, S. Y. Lim, S. H. Sung, and Y. C. Kim, "Inhibition of inducible NO synthase, cyclooxygenase-2 and interleukin- $1 \beta$ by torilin is mediated by mitogen-activated protein kinases in microglial BV2 cells," British Journal of Pharmacology, vol. 156, no. 6, pp. 933-940, 2009.

[26] M. Endale, W. M. Lee, Y.-S. Kwak et al., "Torilin ameliorates type II collagen-induced arthritis in mouse model of rheumatoid arthritis," International Immunopharmacology, vol. 16, no. 2, pp. 232-242, 2013.

[27] M. Endale, S. D. Kim, W. M. Lee et al., "Ischemia induces regulator of G protein signaling 2 (RGS2) protein upregulation and enhances apoptosis in astrocytes," American Journal of Physiology - Cell Physiology, vol. 298, no. 3, pp. C611-C623, 2010.

[28] J. A. DiDonato, M. Hayakawa, D. M. Rothwarf, E. Zandi, and M. Karin, "A cytokine-responsive IkappaB kinase that activates the transcription factor NF-kappaB," Nature, vol. 388, no. 6642, pp. 548-554, 1997.

[29] M. Karin and M. Delhase, "The I $\kappa$ B kinase (IKK) and NF$\kappa \mathrm{B}$ : key elements of proinflammatory signalling," Seminars in Immunology, vol. 12, no. 1, pp. 85-98, 2000.

[30] J.-H. Shim, C. Xiao, A. E. Paschal et al., “TAK1, but not TAB1 or TAB2, plays an essential role in multiple signaling pathways in vivo," Genes \& Development, vol. 19, no. 22, pp. 2668-2681, 2005.

[31] J. A. Hoffmann, F. C. Kafatos, C. A. Janeway Jr., and R. A. B. Ezekowitz, "Phylogenetic perspectives in innate immunity," Science, vol. 284, no. 5418, pp. 1313-1318, 1999.

[32] S. Ghosh, M. J. May, and E. B. Kopp, "NF- $\kappa$ B and rel proteins: evolutionarily conserved mediators of immune responses," Annual Review of Immunology, vol. 16, pp. 225-260, 1998.

[33] S. Chen, "atural products triggering biological targets-a review of the anti-inflammatory phytochemicals targeting the arachidonic acid pathway in allergy asthma and rheumatoid arthritis," Current Drug Targets, vol. 12, no. 3, pp. 288-301, 2011.

[34] M. Caivano and P. Cohen, "Role of mitogen-activated protein kinase cascades in mediating lipopolysaccharide-stimulated induction of cyclooxygenase- 2 and IL- $1 \beta$ in RAW264 macrophages," The Journal of Immunology, vol. 164, no. 6, pp. 3018-3025, 2000. 
[35] N. R. Bhat, P. Zhang, J. C. Lee, and E. L. Hogan, "Extracellular signal-regulated kinase and p38 subgroups of mitogenactivated protein kinases regulate inducible nitric oxide synthase and tumor necrosis factor- $\alpha$ gene expression in endotoxin-stimulated primary glial cultures," The Journal of Neuroscience, vol. 18, no. 5, pp. 1633-1641, 1998.

[36] J. J. Baldassare, Y. Bi, and C. J. Bellone, "The role of p38 mitogenactivated protein kinase in IL-1 $\beta$ transcription," The Journal of Immunology, vol. 162, no. 9, pp. 5367-5373, 1999.

[37] D. Hwang, B. C. Jang, G. Yu, and M. Boudreau, "Expression of mitogen-inducible cyclooxygenase induced by lipopolysaccharide: mediation through both mitogen-activated protein kinase and NF- $\kappa \mathrm{B}$ signaling pathways in macrophages," Biochemical Pharmacology, vol. 54, no. 1, pp. 87-96, 1997.

[38] P. A. Scherle, E. A. Jones, M. F. Favata et al., "Inhibition of MAP kinase kinase prevents cytokine and prostaglandin E2 production in lipopolysaccharide-stimulated monocytes," The Journal of Immunology, vol. 161, no. 10, pp. 5681-5686, 1998.

[39] A. A. Ajibade, H. Y. Wang, and R.-F. Wang, "Cell type-specific function of TAK1 in innate immune signaling," Trends in Immunology, vol. 34, no. 7, pp. 307-316, 2013.

[40] E. J. Kim, H. K. Jin, Y. K. Kim et al., "Suppression by a sesquiterpene lactone from Carpesium divaricatum of inducible nitric oxide synthase by inhibiting nuclear factor- $\kappa \mathrm{B}$ activation," Biochemical Pharmacology, vol. 61, no. 7, pp. 903-910, 2001.

[41] J. Whan Han, B. Gon Lee, Y. Kee Kim et al., "Ergolide, sesquiterpene lactone from Inula britannica, inhibits inducible nitric oxide synthase and cyclo-oxygenase- 2 expression in RAW 264.7 macrophages through the inactivation of NF- $\kappa \mathrm{B}$," British Journal of Pharmacology, vol. 133, no. 4, pp. 503-512, 2001.

[42] Y. Wang, G. Huang, P. Vogel, G. Neale, B. Reizis, and H. Chi, "Transforming growth factor beta-activated kinase 1 (TAK1)dependent checkpoint in the survival of dendritic cells promotes immune homeostasis and function," Proceedings of the National Academy of Sciences of the United States of America, vol. 109, no. 6, pp. E343-E352, 2012.

[43] Y. Y. Wan, H. Chi, M. Xie, M. D. Schneider, and R. A. Flavell, "The kinase TAK1 integrates antigen and cytokine receptor signaling for T cell development, survival and function," Nature Immunology, vol. 7, no. 8, pp. 851-858, 2006.

[44] S. Sato, H. Sanjo, T. Tsujimura et al., "TAK1 is indispensable for development of $\mathrm{T}$ cells and prevention of colitis by the generation of regulatory T cells," International Immunology, vol. 18, no. 10, pp. 1405-1411, 2006.

[45] J. Schuman, Y. Chen, A. Podd et al., "A critical role of TAK1 in Bcell receptor-mediated nuclear factor $\kappa \mathrm{B}$ activation," Blood, vol. 113, no. 19, pp. 4566-4574, 2009. 


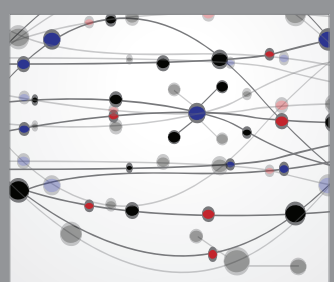

The Scientific World Journal
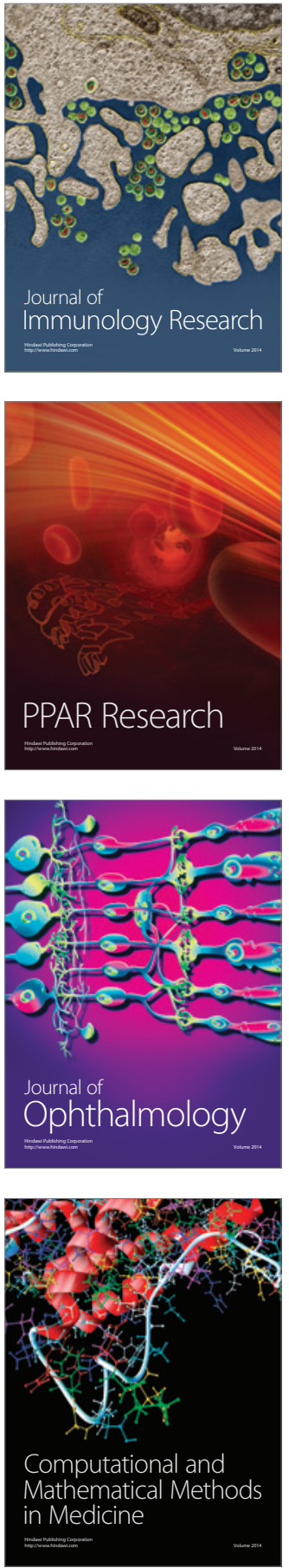

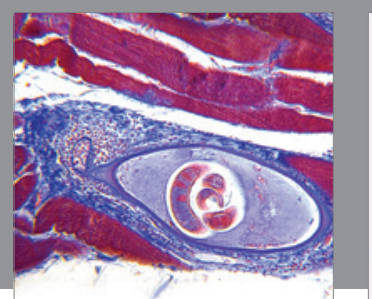

Gastroenterology Research and Practice
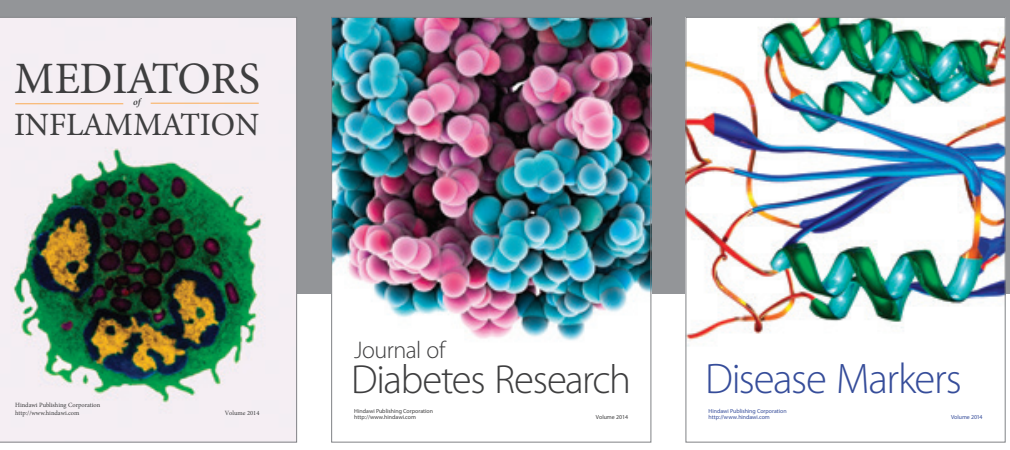

Disease Markers

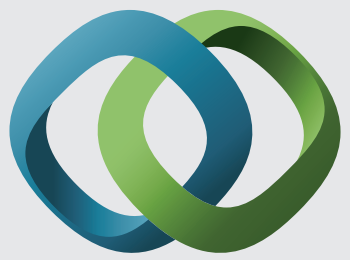

\section{Hindawi}

Submit your manuscripts at

https://www.hindawi.com
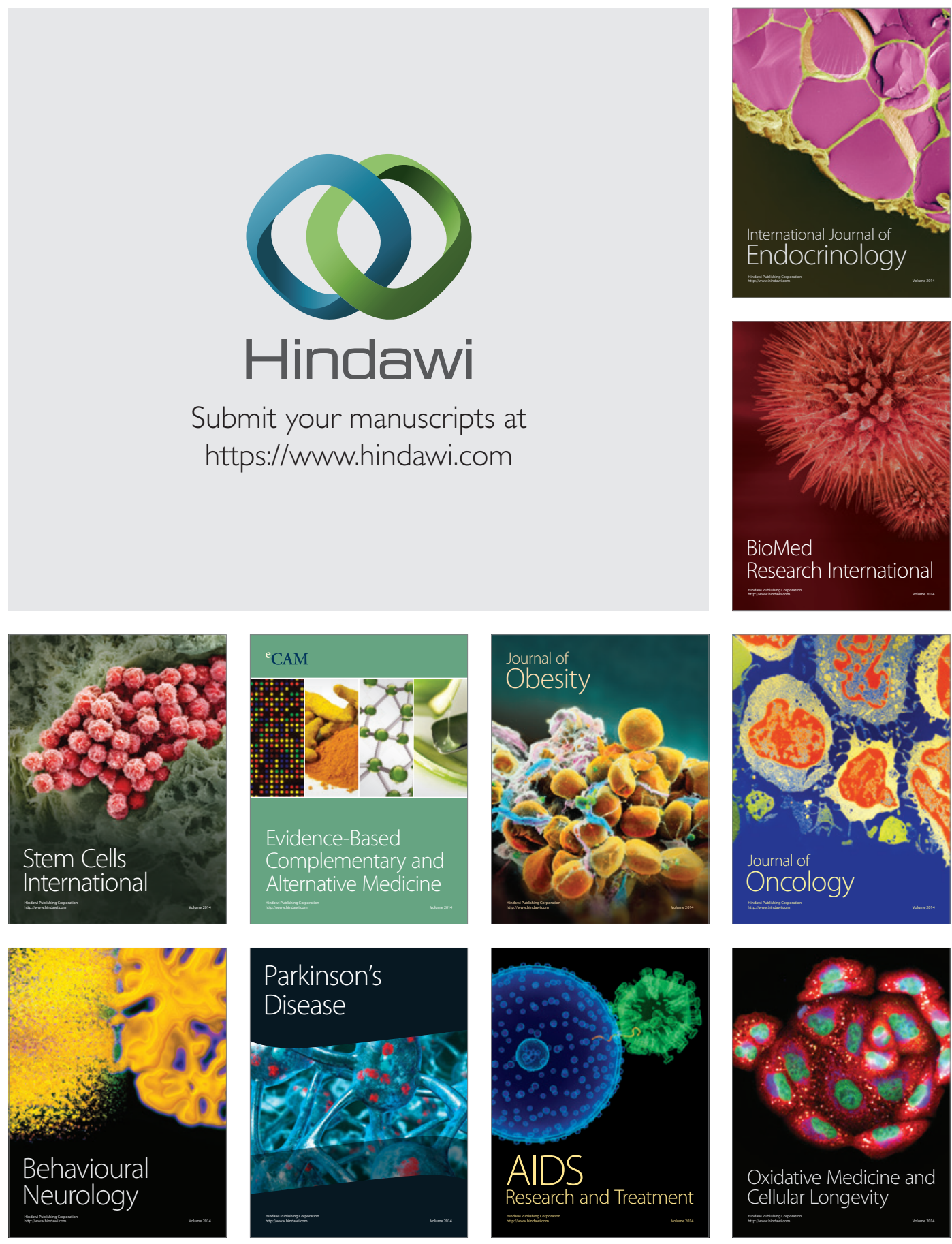